\title{
CASE COMMENT: $R$. v. BATA INDUSTRIES LTD.
}

\section{N.J. STRANZ*}

On February 7, 1992 Judge Ormston of the Ontario Court of Justice, Provincial Division, handed down a precedent-setting decision in R. v. Bata Industries Ltd. ("Bata") by imposing personal liability on three directors of Bata Industries Ltd. ("Bata") for pollution offenses. The Bata decision is important in two respects. First, it delineates a "minimum profile" against which directors liability for environmental offenses can be measured. Second, the penalties imposed by the Court indicate the increasing resolve of the courts to find creative and forceful means of discouraging corporations, directors and senior management from turning a blind eye to, or avoiding involvement in, environmental problems at the workplace.

Evidence in the Bata case disclosed that there were leaking and foaming waste drums stored outside the corporation's premises, from which liquid material waste from Bata's shoe manufacturing plant was being discharged into the ground, thereby contaminating the underlying groundwater. Because there was no proper system in place to prevent the disintegration and leaking of the waste barrels, the Court found there to be a illegal "deposit" of waste. In defence, Bata argued that it exercised "due diligence" in its activities and that there was no evidence of impairment of the groundwater, but the Court found that Bata did not establish, on a balance of probabilities, that it had taken all reasonable steps to prevent the commission of an offence. Furthermore, Judge Ormston found the directors and managers who had personal knowledge of the waste problem personally liable.

In discussing the liability of corporate officers and directors, the Court determined that the legal standard by which personal liability is determined depends on the individual's authority to control the activities giving rise to an offence, as well as such individual's specific responsibility for health and safety practices within the corporation. Quoting a 1989 United States case, Michigan Natural Resources Commission v. Arco Industries, the Court found that the test for directors' liability amounted to "corporate and societal responsibility - responsibility implicitly undertaken by the acquisition of increased power or authority within the corporation and responsibility explicitly undertaken by job description or agreement."

Based on his review of articles, texts and case precedents relating to environmental liability, Judge Ormston distilled a "minimum profile" against which directors' liability could be measured. In assessing whether sufficient "due diligence" has been exercised so as to exculpate the directors from liability, the Court asked the following questions:

Did the Board of Directors establish a pollution prevention "system." (i.e. Was there supervision or inspection? Was there improvement in business matters? Did [the Director] exhort those whom he controlled or influenced [to comply with environmental standards]?" And did each Director ensure that

LL.B., J.D., Barrister \& Solicitor. 
the Corporate officers [were] instructed to set up a system sufficient within the terms and practices of its industry of ensuring compliance with environmental law, ensure that the officers report back periodically to the Board on the operation of the system, and ensure that the officers are instructed to report any substantial non-compliance to the Board in a timely manner?"

In addition, Judge Ormston noted that Directors are responsible for the following [paraphrased]:

Reviewing the environmental compliance reports provided by the officers of the corporation, (but are justified in placing reasonable reliance on reports provided to them by corporate officers, consultants, counsel or other informed parties);

Substantiating that the officers are prompt in addressing environmental concerns brought to their attention by government agencies or other concerned parties including shareholders;

Being aware of the standards of their industry and other industries which deal with similar environmental pollutants or risks;

Immediately and personally reacting when they have noticed the system has failed.

Additionally, and in accordance with the nature of the activity involved, Judge Ormston found that "due diligence" might require that the corporate entity have remedial and contingency plans for spills, a system of on-going environmental audit, training programs, personnel with sufficient authority to act, and other indices of a pro-active environmental policy.

As a supplement to his "minimum profile," Judge Ormston introduced the "doctrine of responsible share," taken from American jurisprudence, to impose liability on one director. By virtue of this doctrine, although that director was not found to be directly liable for the offensive activity, he was found to share in the responsibility for the results of the contamination because he did not exercise a degree of supervision and control that demonstrated he had made an effort to ensure an accepted standard of behaviour was met by those over whom he had influence or control. Thus, the Bata case stands for the principle that a director not only has a responsibility to instruct those whom he controls, he also has a responsibility to ensure his instructions are carried out.

The Court fined Bata a total of $\$ 120,000, \$ 60,000$ of which originated from a single charge under The Ontario Water Resources Act relating to the discharge of contaminants. In addition, two Bata executives were each given 90 days to pay a personal find of $\$ 12,000$ each for their respective convictions under the Ontario Environmental Protection Act. To ensure his message hit home, Judge Ormston, forbade Bata from paying its directors' fines. Other penalties of note included the Court's direction that Bata publish details of the decision both in its worldwide newsletter, and in a worldwide technical circular which was to be issued. Bata was also required to register a caution on the land title for the contamination site, warning of contamination. 